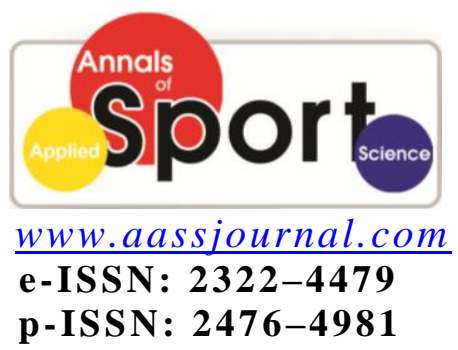

Driginal Article

Received: 22/10/2014

Accepted: 28/01/2015

\title{
The Role of Mass Media in the Development of Private Sector Participation in Sports ${ }^{1}$ Sedigheh Mahmoodi Sahebi*, ${ }^{2}$ Seyed Mohammad Hossein Razavi, ${ }^{2}$ Hamid Ghasemi
}

1. Department of Sport Management, Faculty of Physical Education and Sport Science, Shomal University, Amol, Iran.

2. Department of Sport Management, Faculty of Physical Education and Sport Science, University of Mazandaran, Babolsar, Iran.

3. Department of Physical Education and Sport Science, Karaj Branch, Payam Noor University, Karaj, Iran.

\begin{abstract}
In the present research, the role of the mass media in the development of private sector participation in Mazandaran Province sports was studied. For this purpose, a sample of 130 individuals consisting of sports experts and managers and media executives participated in the survey. In the poll process, a researcher-made questionnaire was utilized after its content validity was confirmed by a number of experts in sports management and its construct validity was approved by the exploratory factor analysis and confirmatory factor with the LISREL software. Its reliability was determined to be 0.91 by Cronbach's alpha. The results indicated that the mass media's roles of awareness and information, education, publicity, and culture-making in the development of private sector participation in Mazandaran Province sports are efficient while its role of social partnership has no impact on the development of the mentioned sector on the same ground. The major roles of the mass media in the development of private sector participation in sports in order of priority include culture-making, advertisement, public information, education and social partnership. There were significant differences between the participants' views about the mass media's role in the development of private sector participation in sports. Consequently, the media managers were found to be more willing to involve the private sector in sports.
\end{abstract}

Key Words: Mass media, Private sector, Sports.

Corresponding Author:

Sedigheh Mahmoodi Sahebi

E-mail: mahmoodisahebi89@yahoo.com 


\section{INTRODUCTION}

Privatization is of the most effective and essential strategy to achieve a progressive and dynamic industry and economy which depends on the creation of strong economic, political and social infrastructure and foundations and employment of scientific approaches (1). For its transition from the status quo and reduction of huge costs of public funds, Sports sector is in need of a fundamental review and special attention. One of the most important mechanisms to solve this problem is giving more opportunities to the private sector in this area and preventing the development of roles for government and private sectors of quasigovernmental nature, particularly in operational activities (2). Striking a balance and meeting the needs of different classes in the society based on sports services are not possible with government investments in annual budgets. Hence, a reasonable and practical solution, as experienced in many countries, would be implementing a nongovernmental investment mechanism and encouraging them on this ground (3).

The mass media is one of the important institutions and tools which plays an affective role in the implementation of Article 44 in the Iran's Sports sector. The media have a direct effect on the values and norms of the society as they reach a considerable part of the population/country (4).

Shahlaee and Ghorbanalizadeh (2015) reported that non-realization of television broadcast as a source of income was the most important criterion of economic challenge in privatization priorities of Iranian football clubs from the perspective of experts (1). Zohrabi, Sabonchi, and Roham (2012) showed that the media play a prominent role in the privatization of sports (5). Rajabi et al. (2012) regarded media advertisements and their audience as important factors in attracting sponsorship (6). 16. Khaledian, Mostafaei, and Samadi
(2013) highlighted the role of the media in the development of sports and sports privatization in Iran (7). Sajjadi (1999) corroborated the role of mass media in the privatization and development of sports funding organizations (8).

Since Mazandaran is considered as one of the major sporting areas in the Iran for nurturing potential talents and one of the few provinces achieving much success in various fields of sports, it has the potential of attracting sponsors and investors from the private sector. Propagation on this basis via the mass media, especially within the province can attract public and private investors' opinions and open the area for their entry into this lucrative industry.

Privatization is a process in which the government evaluates the feasibility of transferring its functions and facilities from the public to the private sector at all levels and proceeds to act in recognition of appropriateness. The concept of privatization is indicative of qualifying a public economic entity and opening its doors to market forces regarding data inputs and outputs (4).

In general, reduction in the sizes of government sports organizations, improvement of athletic performance, elimination of financial deficits, establishment of economic equality, depoliticization, economic control of sports, enhancement of competition and adjustment of subsidies and differences in prices are some of the objectives of privatization in sports (9).

The media have a unique role in the globalization and spread of various phenomena such as sports. When the role of the media was not so clear in sporting events, tournament organizers did not have much success. The growing importance of the media in the spread of sports news has gone so far that inattention of media such as television to a sport in the current circumstance practically means a gradual death of that sport. Mass media such as 
radio and television are considered important factors in effecting social change, economic growth, and culture-making of sports. The broadcast media have long been welcomed by people in different communities and sports and sporting events are of great importance to different social groups. Thus, the organization and purposeful operation of these two social institutions will produce an interaction that will capture the people's attention in a community. This means that if the media is welcomed by the community for displaying various sports, then sports will be of interest to the people and community in turn and vice versa (10).

Nowadays, many believe that the media are the society's greatest coaches (7). The mass media leave a great influence on the masses and can be a source of extensive social change (11). The mass media are one of the basic tools for discussing social issues, informing and educating and serve as a significant factor in the formation of social values (7).

In fact, culture encompasses any activities and movements that results in the acquisition of knowledge, ethics, customs and all the sports skills and traditions via the sports media (12). The mass media have efficient roles and functions in cultural fields, from cultural responsibilities to propagation, strengthening and institutionalization of doctrines, beliefs and good behavior in a community. From among the mass media, radio, television and cinema particularly show great capacities in the production and consumption of cultural patterns and are capable of easily directing them through the production and dissemination of specific programs in the cultural movements of a society (13). The effective use of the media allows us to transfer and transmit a message with little cost, even to remote areas, in a short time and save a significant amount of our time and financial resources (14). The media, particularly mass media, are the major source for raising awareness, changing attitudes and developing healthy behaviors (15).
If the nature of the programs and the contents of messages transmitted or published are for leisure and entertainment, the media would be seeking an entertainment-based role, but if they tend to impress on the spirit, attract attention to something, or create a belief, then they would be fulfilling an advertising role. For the mentioned purposes, a considerable time of the mass media has been dedicated to perform the roles of producing and broadcasting miscellaneous kinds of entertaining programs and advertising brochures. To make propaganda, the media must identify their audiences' rational motives. They usually get their needed information from sources that are consistent with their thoughts and beliefs. In other words, the message makers and audience receive, see or read the programs that they love (7). As educational tools accompanied with specific training methods, the media can also provide the promotion of public knowledge and awareness, empowerment, informational literacy, and media education. The mass media are effective in shaping people's mindset on the one hand and organize and cause their behavior on the other hand to bring about quite deliberate behaviors within the contexts of social phenomena. The process of education provides knowledge and information that will lead to increased participation. Continuous training can be influential on changing or guiding motives and directing them towards appropriate behavior (13).

Social partnership means an interaction between individuals and ultimately the society (justice). By this, we mean all sports media structures and activities that lead to individuals' social interactions with sports. The media are usually very effective in bringing about behavior patterns. They can contribute to the formation of perceptions and motivations for public participation through their emphasis and salience of choice on the values and norms of various events (13). 
Now, given the undeniable role of the mass media in private sector participation in sports, the question of whether their roles of information, education, advertisement, culture-making, and creation of social partnership influence on the development of private sector participation in sports arises. What are the main functions of the mass media in the development of private sector participation? Are there different participants' views about the role of the mass media in the development of private sector participation in Mazandaran Province sports?

The research hypotheses were developed based on the questions raised. The conceptual model of this research was also designed as in Figure 1.

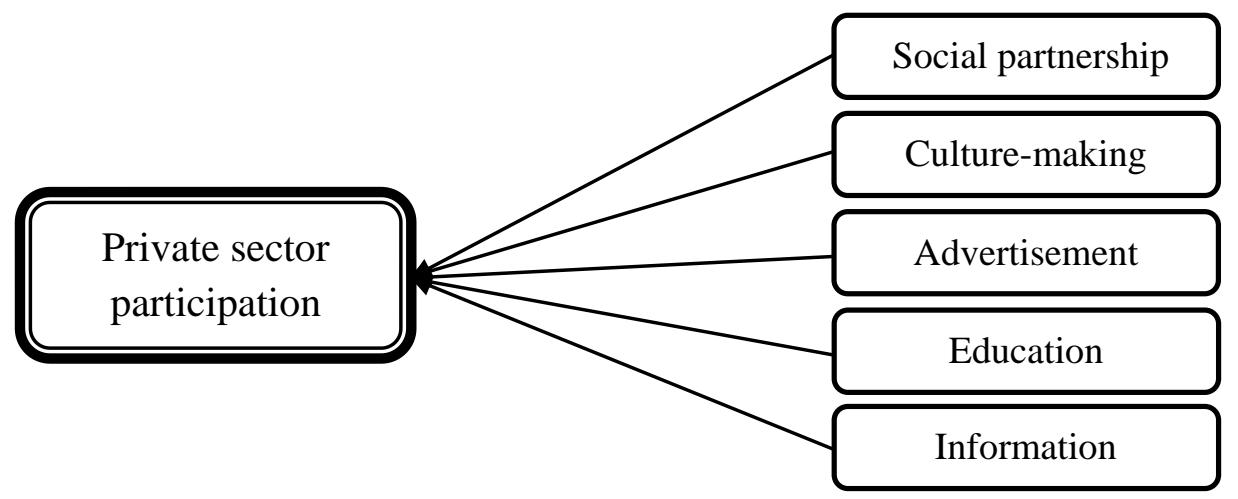

Figure 1. The research conceptual model

\section{MATERIALS AND METHODS}

According to the subject and objectives of the study, the current research is an applied and descriptive survey and a field investigation in terms of data collection.

Participants. Our statistical sample consists of managers and experts in the fields of sports and media in Mazandaran Province. The executive directors of the Sports Department were 100 individuals, including Youth and Sports General Director and Deputies of General Administration, heads of sports bodies, heads of Youth and Sports Departments in the townships of the province, sports experts working in the Department of Youth and Sports of the province and private sector managers, consisting of companies and factories officially licensed by the Directorate General of Youth and Sports Department of Mazandaran Province, all of whom had sports management records. 30 individuals consisting of media managers and experts were individuals, including sports broadcasting managers in Mazandaran Province, TV and radio sports editors, directors in charge of sports journals and athletic websites, as well as sports journalists. The number of samples in this study was considered equivalent to that of the mentioned statistical community, for whom a purposive sampling method was utilized.

Tools. The questionnaire consisted of 25 questions. Questions 1 to 4,5 to 8,9 to 14 , 15 to 18,19 to 22 and 23 to 25 relate to the roles of information, education, advertisement, culture-making, social partnership, and private sector participation in sports, respectively. The questions were evaluated based on a 5-point Likert scale from 1 (low) to 5 (very high). Cronbach's alpha of the variables and questionnaire were obtained as 0.74 and 0.91 , respectively, suggesting that the questionnaire had a good reliability and validity and could serve as a suitable tool for measuring research variables. Also, to assess validity, credit factors including the two types of 
exploratory and confirmatory factor analyses were utilized using LISREL software. Additionally, 13 experts and academics' views were used to verify the content validity of the questionnaire.

Statistical Analysis. By following the proposed method of Gerbing and Anderson (1988), a two-stage approach was adopted where in the first stage the measures employed were examined and in the second phase, the relationships and assumptions raised were discussed. To this end, first, the degree of explanation of each variable by any of the questions associated with them was addressed and thus an exploratory and confirmatory factor analyses was applied. After this application, all the measures had a factor loading value higher than 0.5 . The statistical index of sampling adequacy of each of the structures was also greater than 0.6, indicating adequate sampling. Moreover, the significant values obtained from Bartlett's test of all the structures was smaller than 0.05, showing that it is not a single matrix and a factor analysis can still be benefited from to identify the structure. LISREL software output for the confirmatory factor analysis showed that all the figures were significantly higher than 1.96. Therefore, it can be stated that all the questions in the questionnaire could be used in data analyses.

\section{RESULTS}

To analyze the data and test the research hypotheses, a structural equation modeling was employed. The results revealed the significant coefficients of the media's informational, educational, advertising, culture-making, and social partnership roles for private sector participation were 5.15, 4.13, 6.32, 8.25, and 1.37, respectively.

As seen in Figure 2 and Table 1, the standard coefficients for the abovementioned roles of the media are $0.49,0.35$, $0.56,0.73$, and 0.15 , respectively.

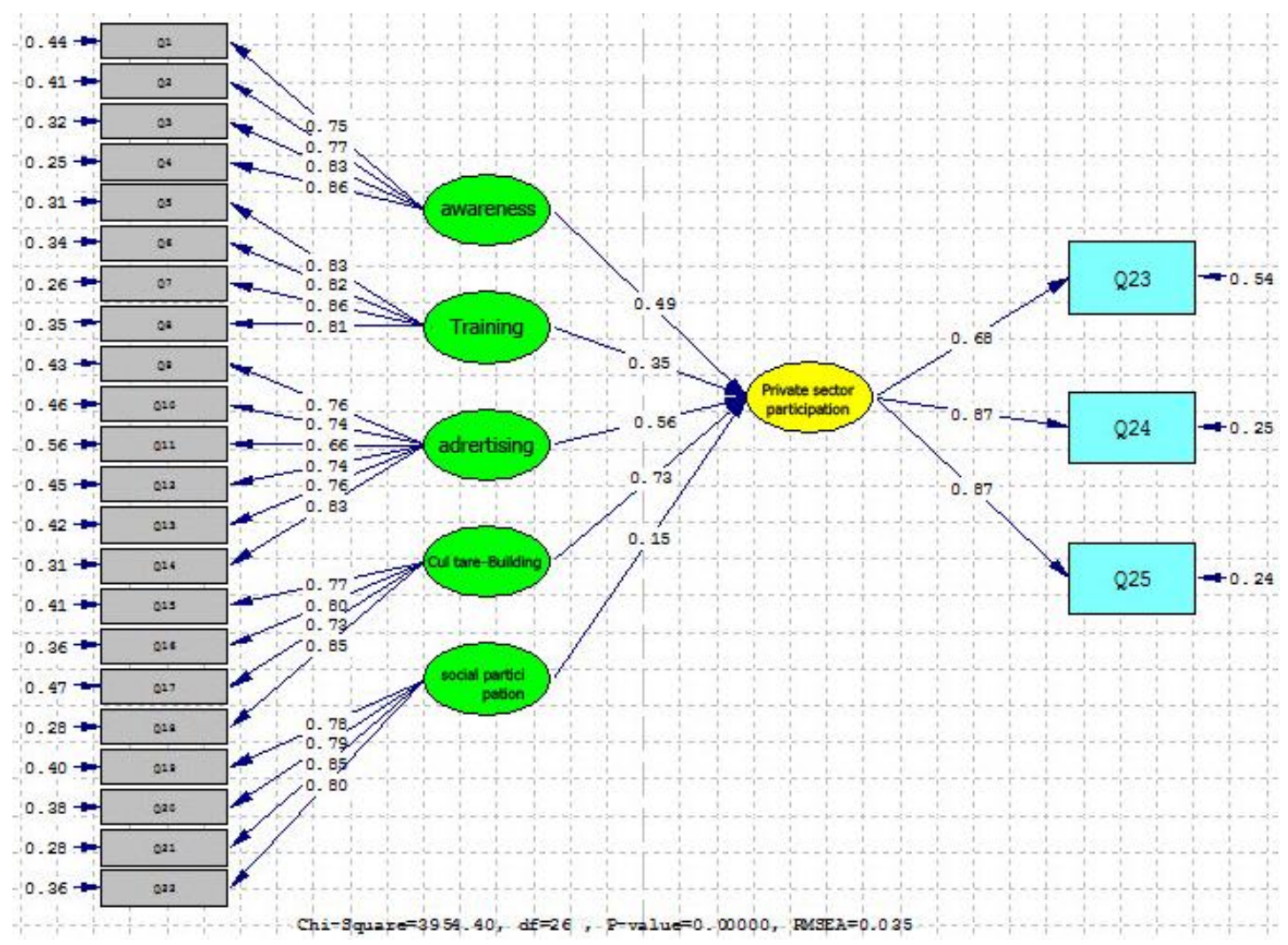

Figure 2. The model of standard coefficients for the research hypotheses 
To evaluate the differences between media and sports managers and staff's perspectives about private sector participation, comparison of means test was used.

As shown in Table 2, a significant difference exists between the media and sport managers and experts' opinions about private sector participation since the average participation value of the media's managers (3.2262) is lower than that of sports managers (3.8744) at 0.001 significance level.

Table 1. Standardized path coefficients of the direct effects of the research model variables

\begin{tabular}{|c|c|c|c|c|}
\hline Path & $\begin{array}{c}\text { Standard } \\
\text { coefficient }\end{array}$ & Sig & $\begin{array}{l}\text { Acceptance } \\
\text { or } \\
\text { rejection }\end{array}$ & Prioritization \\
\hline $\begin{array}{l}\text { Role of awareness participation enhancement of private sector } \\
\text { participation }\end{array}$ & 0.49 & 5.15 & Accept & First \\
\hline $\begin{array}{l}\text { Role of training participation enhancement of private sector } \\
\text { participation }\end{array}$ & 0.35 & 4.13 & Accept & Fourth \\
\hline $\begin{array}{l}\text { Role of advertising participation enhancement of private sector } \\
\text { participation }\end{array}$ & 0.56 & 6.12 & Accept & Second \\
\hline Role of culture participation enhancement of private sector participation & 0.73 & 8.25 & Accept & $\mathrm{Fi}$ \\
\hline Role of social participation enhancement of private sector participation & 0.15 & 1.37 & Reject & Fifth \\
\hline
\end{tabular}

Table 2. Comparison of means for the two communities

\begin{tabular}{cccccc}
\hline Managers' & Frequency & Mean & Standard & T rate & \multirow{2}{*}{ Sig } \\
Participation & $(\mathrm{N})$ & 3.226 & 0.53713 & & \multirow{2}{*}{0.001} \\
Media & 28 & 3.8744 & 0.700096 & -4.376 & \\
Sports & 65 & & \\
\hline
\end{tabular}

\section{DISCUSSION AND CONCLUSION}

The aim of this study was to investigate the role of the mass media in the development of private sector participation in sports in Mazandaran Province. According to the results of our hypotheses, , it is suggested that those involved in sports should pay attention to the potential uses of mass media to help sports and sports organizations take advantage of private sector participation, a similar issue noted in Amiri et al. (2012) research (2). The media are influential in informing the benefits of private sector participation in sports. This study also emphasizes people's awareness in attracting financial support and private sector investors for sports by the media. The mass media have a significant impact on creating awareness on how the private sector engages as well as the benefits of its participation in sports. Furthermore,
Ekmekci (2013) and Osborn (2013) stressed the importance of the mass media in disseminating information in sports to attract more investments from the private sector $(16,17)$.

The results of this research showed that the media affects education for the development of private sector participation in sports. By offering educational programs on how to engage the private sector in sports and its different ways of cooperation with it, they can provide the basis for investors' participation in this sector. This result is in line with those of Amiri et al. (2012), Moradi, Honari, and Ahmadi (2012), and Meenaghan, McLoughlin, and McCormack (2013), which corroborates that audiences and people's training is a method of private sector engagement in sports $(2,12,18)$.

The findings also suggest that the advertising role of mass media is effective 
on private sector participation in sports and this role is one of its most important functions that significantly influence the attraction of private sector investment in sports. This is congruent with the research results of Amiri et al. (2012), Roushandel Arbatani (2007), Ekmekci (2013), and Osborn (2013) (2, 11, 16, 17). In their studies, it was stated that the mass media attract more private sector investors in sports by advertising privatization and investments in this field, as well as private sector goods and services with the help of sports and sporting events. Osborn (2013) stated that advertising at sports events and programs is one of the best ways to familiarize customers with the names, products, and services of the private sector (17).

In this study, it was shown that the media can influence on the beliefs and cultures of its audiences. Using leverage and their effects, they can change people's attitudes, values, and culture, thus institutionalizing a specific culture. The research of Rajabi et al. (2012) and Meenaghan, McLoughlin, and McCormack (2013) also ratified the important role of the mass media's culturemaking $(6,18)$.

However, the results of the current study revealed that the role of the mass media in social partnership is not influential on the development of private sector participation in sports, which is inconsistent with the research results of Amiri et al. (2012), Moradi, Honari, and Ahmadi (2012), and Meenaghan, McLoughlin, and McCormack (2013) $(2,12,18)$. The reason for this incongruence could be the fact that previous researches were carried out in the field of athletics and sports that only involved championship from samples' perspectives.

The results also showed that there is a difference between administrators and experts' perspectives of the media and Sports Department. Our results indicated that the media's managers and professionals are more likely to privatize sports and attract private sector participation in Mazandaran Province Sports. This could be due to further studies and awareness of the managers and experts of this sector. Also, since most sites and sports programs of Mazandaran Province are of analytical aspects, sports managers and mass media in this province are more aware of problems facing sports and their causes and thus well know the benefits of private sector participation in sporting activities of the province and the need for their privatization at club levels.

The overall result of this investigation is indicative of the highly significant role of the mass media in creating a favorable environment for private sector participation and investment in sports in Mazandaran Province. With their potential capacities, the media are able to serve as one of the most effective tools for sports privatization and private sector participation and consequently cause sports prosperity and development in the province.

\section{APPLICABLE REMARKS}

- It is suggested that athletic directors and media managers give priority to the creation of a suitable basis for the attraction of private sector investment to develop the province's sports and consider their privatizationas a major decision with the help of the mass media.

- It is necessary that this issue be pursued and monitored by managers, supervisors and experts at every level of sport organizations and different sectors of sports media with seriousness and planned priority. 


\section{REFFRENCES}

1. Shahlaee J, Ghorbanalizadeh Ghaziani F. Privatization Priorities of Iranian Football Clubs from the Perspective of Experts. Annals of Applied Sport Science. 2015;3(2):57-68.

2. Amiri M, Nayyeri S, Saffari M, Delbari F, Ragheb. Media and Enhancement of Private Sector Participation in Sports Sector. Quarterly Journal of Communication Research. 2012;19(1):9-38 [Article in Farsi].

3. Razavi SMH, Khosh Chehreh M, Asadi H, Kazemnezhad A. Sports Privatization with Emphasis on Athletics. Olympic. 2005;12(4):75-86 [Article in Farsi].

4. Kianpour S. Overview of privatization in several countries, referring to the general policies of Article 44 . Business Studies. 2009;7(38):2-20 [Article in Farsi].

5. Zohrabi F, Sabonchi R, Roham M. The role of media in economic jihad of championship sports. Management and Organizational Behavior in Sport. 2012;1(1):13-9 [Article in Farsi].

6. Rajabi M, Soltan Hoseini M, Razavi MH, Hoseini E. The Role Of Medias And Spectators In Attracting The Private Sector Investment In Championship Sport. Sport Management Review. 2012;4(13):93-106 [Article in Farsi].

7. Khaledian M, Mostafaei F, Samadi M, Kia F. The role of mass media in the development of sport. Communication Management in Sport Media. 2013;1(2):48-55 [Article in Farsi].

8. Sajjadi N. Analysis of the role of mass media in the 20th century Olympic Games. Harakat. 1999;1(3):39-56 [Article in Farsi].

9. Khorshidi A, Shahbazi K. An introduction to Terms and Accessories of privatization in sport. Tehran, Iran: Research Center of Iranian Islamic Parliament, 2011 Contract No.: 270.

10. Azadan M, Askarian F, Ramezaninejad R. An Investigation Into The Ways Of Sponsor's Attraction To Iran Professional Football. Sport Management Review. 2012;4(13):123-36 [Article in Farsi].

11. Roushandel Arbatani T. The Explanation Of Mass Media Status In Institutionalization Of Public Sports In Iran. Harakat. 2007(33):165-77 [Article in Farsi].

12. Moradi M, Honari H, Ahmadi A. A comparison between Effective Subcomponents of IRIB's Roles in terms of Informing, Social Participation, Training and Culture-building with Regard to Popular Sports. Quarterly Journal of Communication Research. 2012;18(4):51-70 [Article in Farsi].

13. Motamednezhad K. Social communication tools. 9th ed. Tehran, Iran: Allameh Tabataba'i University Publication; 2014 [Book in Farsi]. 378 p.

14. Rahimi F, Khankelabi M. Internet use in patients with spinal cord injury. Research and Assessment. 2007;14(50):112-33 [Article in Farsi].

15. Ramzankhani A, Ghanbari S. The role of media in disease prevention. Research and Assessment. 2007;14(50):931 [Article in Farsi].

16. Ekmekci R. New Era Sport Sponsorship in Turkey. Journal of Business and Management Sciences. 2013;1(1):103.

17. Osborn JC. Benefits of advertising and marketing during televised sporting events. 2013.

18. Meenaghan T, McLoughlin D, McCormack A. New Challenges in Sponsorship Evaluation Actors, New Media, and the Context of Praxis. Psychology \& Marketing. 2013;30(5):444-60. 
تازههاى علوم كاربردى ورزش

دوره سوم، شماره سوم

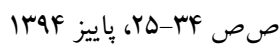

مقاله اصيل

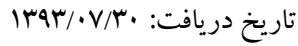

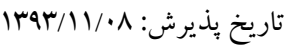

\title{
بررسى نقش رسانههاى جمعى در توسعه مشار كت بخش خصوصى در ورزش استان مازندران
} 'صديقه محمودى صاحبى *' "سيد محمد حسين رضوى، "حميد قاسمى

\begin{abstract}
ا. كارشناسى ارشد مديريت ورزشى، دانشكده تربيت بدنى و علوم ورزشى دانشخاه غيرانتفاعى شمال، أمل، ايران.

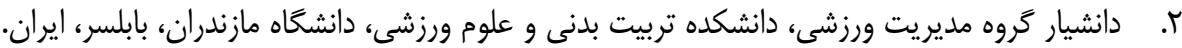

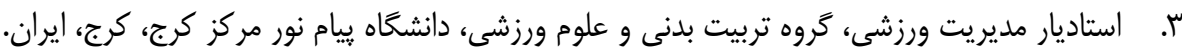

קֶكيده

در اين تحقيق نقش رسانههاى جمعى در توسعه مشاركت بخش خصوصى در ورزش استان مازندران مورد بررسى قرار كرفت. بدين منظور • با

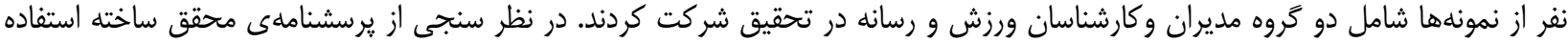

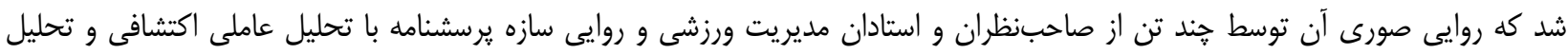

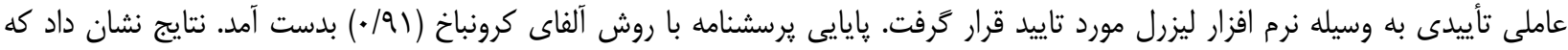

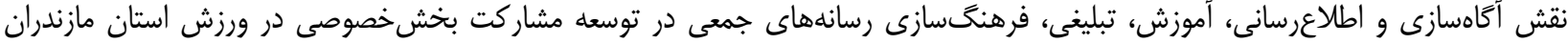

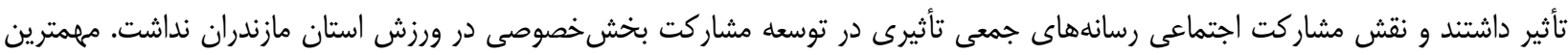

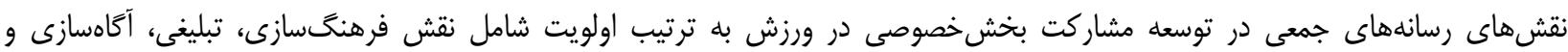

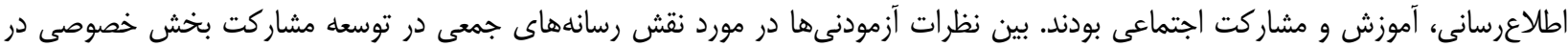
ورزش تفاوت معنادارى وجود داشت، مديران بخش رسانه تمايل بيشترى به مشاركت بخش خصوصى در ورزش داشتند. وازَّان كليدى: رسانهاى جمعى، بخش خصوصى، ورزش. 
